\title{
Yield and Nutritional Quality of Green Leafy Lettuce (Lactuca sativa L.) under Soilless Culture System Using Various Composition of Growing Media and Vermicompost Rates
}

\author{
Nurhidayati $^{1 *}$, Masyhuri Machfudz ${ }^{2}$ and Abdul Basit ${ }^{1}$ \\ ${ }^{1}$ Department of Agrotechnology, Faculty of Agriculture, University of Islam Malang, Malang, Indonesia; \\ ${ }^{2}$ Department of Agribusiness, Faculty of Agriculture, University of Islam Malang, Malang, Indonesia \\ ${ }^{*}$ Corresponding author: nurhidayati@unisma.ac.id
}

\begin{abstract}
Soilless culture system (SCS) production is preferred because it is more hygienic and highly nutritious and free of chemical pesticides. However, the application of organic fertilizers in SCS for green vegetable cultivation is still rarely used. This study was to test various growing media compositions and vermicompost rates on green lettuce's nutritional quality. Four types of growing media (using the mixture of cocopeat, zeolite, rice husk biochar and sand) and five levels of vermicompost rates $\left(50-250 \mathrm{~g} \mathrm{pot}^{-1}\right)$ were tested. The greatest total fresh weight and marketable yield were found using $55 \%$ cocopeat, $30 \%$ rice husk biochar and $15 \%$ sand with a vermicompost rate of $250 \mathrm{~g} \mathrm{pot}^{-1}$. The highest nutritional quality of green lettuce as measured by the highest content of chlorophyll A, B, the total chlorophyll and calcium (Ca) was found in the composition of cocopeat $55 \%$, zeolite $30 \%$ and sand $15 \%$. As was, the highest mineral content of of potassium $(\mathrm{K})$ and phosphorus $(\mathrm{P})$. Good quality lettuce was found in growing media using 30\% biochar with a vermicompost rates of 200-250 $\mathrm{g} \mathrm{pot}^{-1}$ and growing media using $30 \%$ zeolite with a vermicompost rates of $150-200 \mathrm{~g} \mathrm{pot}^{-1}$. Thus, the admixtures of biochar and zeolite into the cocopeat substrate for the soilless culture system of green leafy lettuce significantly affected yield and nutritional quality.
\end{abstract}

Keywords: chlorophyll content; mineral content; organic fertilizer; soilless cultivation

Cite this as: Nurhidayati, Machfudz, M., \& Basit, A. (2021). Yield and Nutritional Quality of Green Leafy Lettuce (Lactuca sativa L.) under Soilless Culture System Using Various Composition of Growing Media and Vermicompost Rates. Caraka Tani: Journal of Sustainable Agriculture, 36(2), 201-212. doi: http://dx.doi.org/ 10.20961/carakatani.v36i2.46131

\section{INTRODUCTION}

In the next 40 years, the world population is projected to increase from 7.0 billion to 9.5 billion people (United Nations, 2019). The population in Indonesia is also increasing from year to year. Many problems have arisen in line with the increase in population in Indonesia. Humans need water, food and living habitat to sustain life. These things do not occur in abundance in nature. These human needs come from both abiotic and biotic sources. Humans must be able to optimize land area and conserve biodiversity. Food production also needs to be increased to meet human food needs. Agricultural production systems generally use soil for plant growth. Soil provides nutrients, water and air for plants (Khan et al., 2018). However, on the other hand, natural resources that support food production are increasingly limited. Therefore, to maintain the sustainability of the plant production system, a cultivation system is needed by utilizing various kinds of places such as balconies, roofs, greenhouses and unsuitable lands for cultivation.

\footnotetext{
* Received for publication November 29, 2020 Accepted after corrections February 8, 2021
} 
This kind of farming system is a landless farming system that operates in controlled conditions to obtain higher productivity and income (El-Kazzaz and El-Kazzaz, 2017).

Soilless culture is a method of growing plants without using soil as a medium for root growth (Savvas, 2003; Gruda et al., 2018). Nowadays soilless culture is proliferating as the primary technology component of greenhouses that use various growing media such as peat, coir, zeolite, etc. This cultivation technique usually uses chemical fertilizers for nutrition (Asaduzzaman et al., 2015). Growing medium which is termed as "substrate" is defined as any solid material (alone or in mixtures) excluding soil, which guarantee better plant growth conditions than agricultural soil in one or many aspects (Gruda et al., 2013). Growing media has been widely used in high-value vegetable and ornamental plant production and plant propagation, such as in nurseries and container crop production. Generally, the horticultural industry employed solid mixture material as growing media. This planting medium can be either organic or inorganic (Savvas, 2003; Savvas et al., 2013).

The community's favors of the soilless cultivation system is increasing due to its advantages, including the independence from the soil as a heterogeneous natural planting medium which sometimes contains pathogens detrimental to plants (Gruda et al., 2016). Despite the initial high capital investment, the fast and high production rate offsets the initial investment costs within the first 3-4 years under ideal system production. Another advantage is that the soilless cultivation system can optimize plant root development and minimize plant pests and diseases (Asaduzzaman et al., 2015). As a result, this soilless culture system has higher yields, lower production costs due to the minimal use of chemical pesticides, higher quality of food products and stable productivity (Gruda et al., 2018).

According to Rembialkowska (2007), two main factors which influence food product quality are abiotic and biotic factors. Abiotic factors are related to the environment, such as water, air and soil. These factors must be free from pollution if the crops obtained are expected to be of high nutritive quality. When pollutants such as pesticide, heavy metals, toxic compound, synthetic organic chemical enter the plant's production system, it creates problems for human health (Science Communication Unit, University of the West of England, 2013). Other environmental factors are soil $\mathrm{pH}$ and type of fertilizers which also affect the quality of food products. Biotic factors include crop damage due to plant pests and diseases. Bacterial and fungal contaminants that cause disease in plants can also reduce the quality of food products. The choice of plant varieties also affects the quality of crop products. Rembialkowska (2007) reported that horticultural plant species such as tomatoes have a higher lycopene content and carrots where some varieties contain higher $\beta$ carotene.

Other researches on the application of organic fertilizers in organic farming systems produces food which contained higher nutritional value, especially vegetable crops (Rembiakowska, 2007). The application of vermicompost to a mixed planting medium of soil and cow manure increased the vitamin $\mathrm{C}$ content of pak-coi mustard compared to treatments using chemical fertilizers (Nurhidayati et al., 2015) as well as cabbage (Nurhidayati et al., 2016). The increase in vitamin $\mathrm{C}$ content in green leafy vegetables grown organically was caused by the lower water and nitrate content of organic vegetables than conventionally grown vegetables using high doses of chemical fertilizers (Williams, 2002). Organic vegetables not only contain higher bioactive compounds such as vitamins, phytochemicals, flavonoids and carotenoid but also contain higher minerals than conventional vegetables, with an average increase of $21.3 \%$ (Worthington, 2001). The application of organic fertilizers to soilless growing media has not been widely used. This study used chemically active growing cocopeat media such as cocopeat, zeolite, rice husk biochar and sand and aimed at testing various compositions of growing media and vermicompost rates on the yield and quality of green leafy lettuce.

\section{MATERIALS AND METHOD}

A pot experiment was conducted in the polyethylene greenhouse of the University of Islam Malang, Indonesia ( $7^{\circ} 93^{\prime} 75^{\prime \prime}$ South Latitude and $112^{\circ} 37^{\prime} 59^{\prime \prime}$ East Longitude) which started in January until May 2020. The polyethylene greenhouse daily temperature varied from $18-30{ }^{\circ} \mathrm{C}$ with a relative humidity of about $45-85 \%$ and light intensity of 375-1892 Candela. 
The materials used for this research were cocopeat, rice husk biochar, zeolite and sand as growing media.

A factorial randomized block design was used. The first factor was the composition of growing media materials, which consisted of four levels $55 \%$ cocopeat, $15 \%$ rice husk biochar and $30 \%$ sand (M1); $55 \%$ cocopeat, $30 \%$ rice husk biochar and $15 \%$ sand (M2); 55\% cocopeat, $15 \%$ zeolite and $30 \%$ sand (M3); and 55\% cocopeat, $30 \%$ zeolite and $15 \%$ sand (M4). The second factor was vermicompost rates which consisted of five levels namely $\mathrm{V} 1=50$ $\mathrm{g} \mathrm{pot}^{-1}, \mathrm{~V} 2=100 \mathrm{~g} \mathrm{pot}^{-1}, \mathrm{~V} 3=150 \mathrm{~g} \mathrm{pot}^{-1}, \mathrm{~V} 4=$ $200 \mathrm{~g} \mathrm{pot}^{-1}$ and V5 $=250 \mathrm{~g} \mathrm{pot}^{-1}$. Each treatment combination was repeated three times, with five samples per replication. The total pot 300 pots were used. The pots were placed with a randomized block design in the polyethylene house. The weight of growing media material in each pot was $1000 \mathrm{~g}$. Before being used as a growing media, cocopeat was fermented using effective microorganisms and molasses for one week. The moisture of growing media was adjusted to $50 \%$ by watering the growing media with water.

The process of vermicompost making was conducted in a container with spent mushroom waste as bedding in the base and top of the vermicomposting container as thick as $5 \mathrm{~cm}$. Earthworm feed in the form of the mixture of cow manure, dry leaf litter and fresh vegetable waste was placed in the middle layer of $10 \mathrm{~cm}$. Then, $0.75 \mathrm{~kg}$ Lumbricus rubellus earthworms were inoculated into the vermicomposting bin for 28 incubation days. The moisture of vermicompost was adjusted to $80 \%$. The output was then composted by adding eggshell flour and fish bone

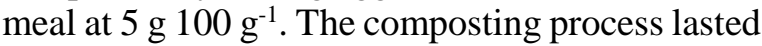
for 14 days. After seven days of composting, dried leaf of Tithonia diversifolia was ground and added into the vermicompost. The vermicompost produced was mixed with growing media one week before planting. The lettuce seeds were used as plant indicators. Lettuce seeds were germinated and plantlets grown for the first 21 days to the four leaves stage and transplanted to the pots seven days after mixing vermicompost with growing media.

The yield of the plant, the content of chlorophyll A, B and total chlorophyll, vitamin $\mathrm{C}$, Phosphorus (P), Potassium (K) and Calcium (Ca) were determined 30 days after planting.
Plant yield was determined as total fresh and dry weight and the fresh weight of the marketable yield.

The content of chlorophyll was measured with the spectrophotometric method using acetone solvent. The vitamin $\mathrm{C}$ content was determined by the iodometric titration method. The $\mathrm{P}, \mathrm{K}$ and $\mathrm{Ca}$ content was determined by the wet combustion method using $\mathrm{HNO}_{3}+\mathrm{HClO}_{4}$ solvent and then measured $\mathrm{Ca}$ content by titration method using Ethylene diamine tetra-acetic acid (EDTA) solvent, using Flame photometer for $\mathrm{K}$ content and UV-Spectrophotometer for $\mathrm{P}$ content (Kalra, 1997).

Data were statistically analyzed using analysis of variance (F-Test) at level $(\mathrm{P} \leq 0.05)$ and differences in each treatment were adjudged by the Tukey test $(\mathrm{P} \leq 0.05)$ using Minitab Version 14.12. For statistical analysis of data (charts), Microsoft Excel was employed.

\section{RESULTS AND DISCUSSION}

\section{Yield of green leafy lettuce}

The growing media composition and the vermicompost rates significantly affected the yield of green leafy lettuce. The composition of the M2 growing medium (55\% cocopeat, $30 \%$ rice husk biochar and 15\% sand) gave the highest yield with a total plant fresh weight of 58.82 $\mathrm{g}$ plant $^{-1}$ and marketable yield fresh weight of $53.70 \mathrm{~g} \mathrm{plant}^{-1}$ (Figure 1).

These results indicated that the composition of the growing media played an essential role in crop yield. Growing media that used biochar produced higher crop yields than the others. The higher the rice husk biochar content, the higher the crop yield. Biochar is the carbon residue produced through the pyrolysis process of biomass, a heating process without oxygen. This process converts the organic matter into a vapor phase and a solid biochar residue (Lehmann and Joseph, 2009). Laird (2008) stated that biochar contained three matters namely recalcitrant $\mathrm{C}$, labile or leachable $\mathrm{C}$ and ash. Biochar has been studied as an amendment in soilless substrates and it has enhanced plant growth and induced systemic resistance of plants to disease (Elad et al., 2010; Graber et al., 2010), thereby increasing crop yields. The yield of green leafy lettuce increased in the growing media consisting biochar. The biochar's had positive effect on 
nutrient availability. Biochar affected nutrient retention and its release (Lehmann et al., 2003; Liang et al., 2006; Biederman and Harpole, 2013). The ability of biochar to retain nutrients has been proven in earlier studies (Clough and Condron, 2010; Altland and Locke, 2012; Barrow, 2012; Cheng et al., 2012; Clough et al., 2013; Farrell et al., 2014).

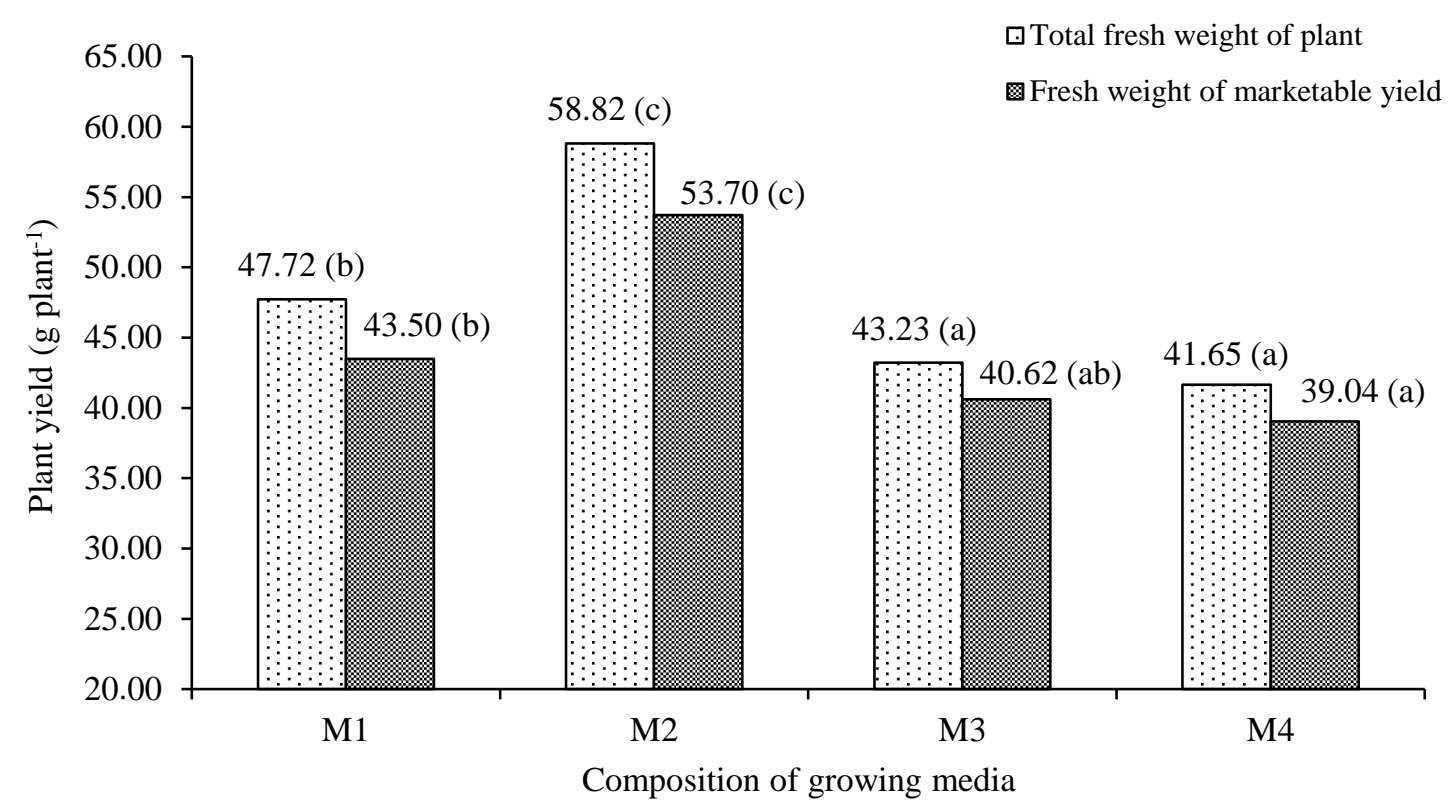

Note: $\mathrm{M} 1=55 \%$ cocopeat, $15 \%$ rice husk biochar and $30 \%$ sand; $\mathrm{M} 2=55 \%$ cocopeat, $30 \%$ rice husk biochar and $15 \%$ sand; $\mathrm{M} 3=55 \%$ cocopeat, $15 \%$ zeolite and $30 \%$ sand; $\mathrm{M} 4=55 \%$ cocopeat, $30 \%$ zeolite and $15 \%$ sand

Figure 1. Effect of various compositions of growing media on green leafy lettuce yield. (Means accompanied by the same letters are not significantly different at Tukey-test, $\mathrm{P}=$ $0.05)$

In a soilless culture, the biochar added up to $10 \%$ by volume decreased nitrate and phosphate leaching by slowing their release over time (Altland and Locke, 2012). Dumroese et al. (2011) studied pelleted biochar in nursery containers and found that substrate containing $75 \%$ peat moss and $25 \%$ pelleted biochar was suitable for use during nursery-crop production. Biochar application into the growing media increased plant growth and yield. The positive effect of biochar has been shown in numerous studies (Steiner et al., 2007; 2008; Vaccari et al., 2011). For example, it is reported that maize yield increased by $98-150 \%$ as a result of manure biochar addition (Uzoma et al., 2011), lettuce and Arabidopsis plant biomass increased by $111 \%$ after the addition of poplar wood chips biochar (Viger et al., 2014) and wheat grain yield increased by $18 \%$ with the use of oil mallee biochar (Solaiman et al., 2010).

Based on the regression equations, the optimum rate which gave the maximum total fresh weight of plants was $278 \mathrm{~g} \mathrm{pot}^{-1}$, while the fresh weight of marketable yield was $292.25 \mathrm{~g} \mathrm{pot}^{-1}$ with yields of $51.17 \mathrm{~g} \mathrm{plant}^{-1}$ and $48.5 \mathrm{~g} \mathrm{plant}^{-1}$, respectively (Figure 2). The optimum rate of vermicompost based on the regression equations exceeded the experimental rate range. Therefore, it cannot be recommended as the best treatment. It also showed that the application of vermicompost at a high rate still showed an increase in yield. Vermicompost has a direct effect on plant growth and yield because it provides $\mathrm{N}, \mathrm{P}, \mathrm{K}, \mathrm{Ca}$ and $\mathrm{Mg}$ for plants, increases the content of soil organic matter, increases soil quality, provides plant growth hormones and acts as soil support (Lazcano and Dominuez, 2011). Reports mentioned that vermicompost increased water retention, especially on porous soils (Jouquet et al., 2010; Jouquet et al., 2011) and the growing media used in this study. Application of vermicompost increased the growth of organic vegetable plants in pots, including pak-coi, cabbage and broccoli (Nurhidayati et al., 2015; 2016; Nurhidayati et al., 2017). 


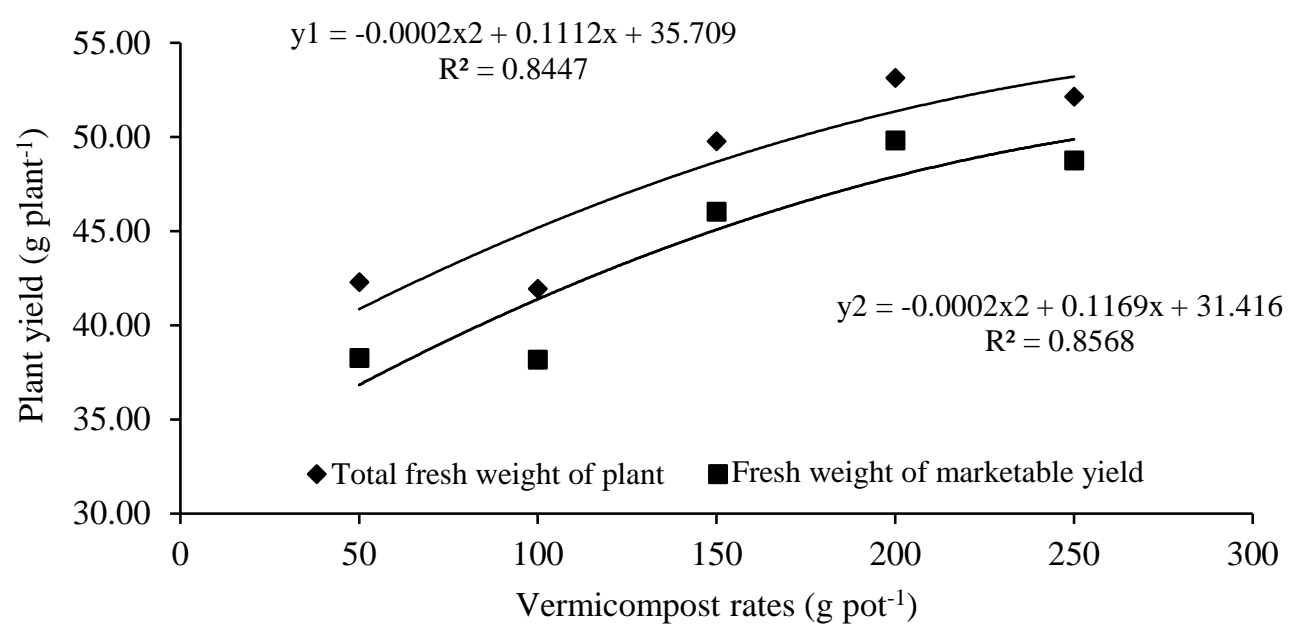

Figure 2. Effect of vermicompost rates on the lettuce yield grown using a soilless culture system

\section{Quality of green leafy lettuce}

The composition of the growing media and the vermicompost rates significantly affected the quality of green leafy lettuce. The composition of the growing medium M4 (55\% cocopeat, $30 \%$ zeolite and $15 \%$ sand) gave higher chlorophyll A, B and total chlorophyll content than the other treatments; which was similar to $\mathrm{M} 2$ (55\% cocopeat, $30 \%$ rice husk biochar and $15 \%$ sand) for chlorophyll A content (Figure 3). Chlorophyll represents an essential pigment for photosynthesis. Chlorophyll synthesis requires many elements, i.e., nitrogen $(\mathrm{N})$, phosphorous $(\mathrm{P})$, from soils or growing media (Fredeen et al., 1990). Water availability also affects chlorophyll synthesis because water is used for transporting nutrients in plants, as mineral salts must be dissolved in water to be absorbed by plants (Li et al., 2018). This study has shown that a higher biochar and zeolite composition has a higher chlorophyll content. This study showed that biochar and zeolite's role in water retention could provide nutrients for plants that affect chlorophyll synthesis.

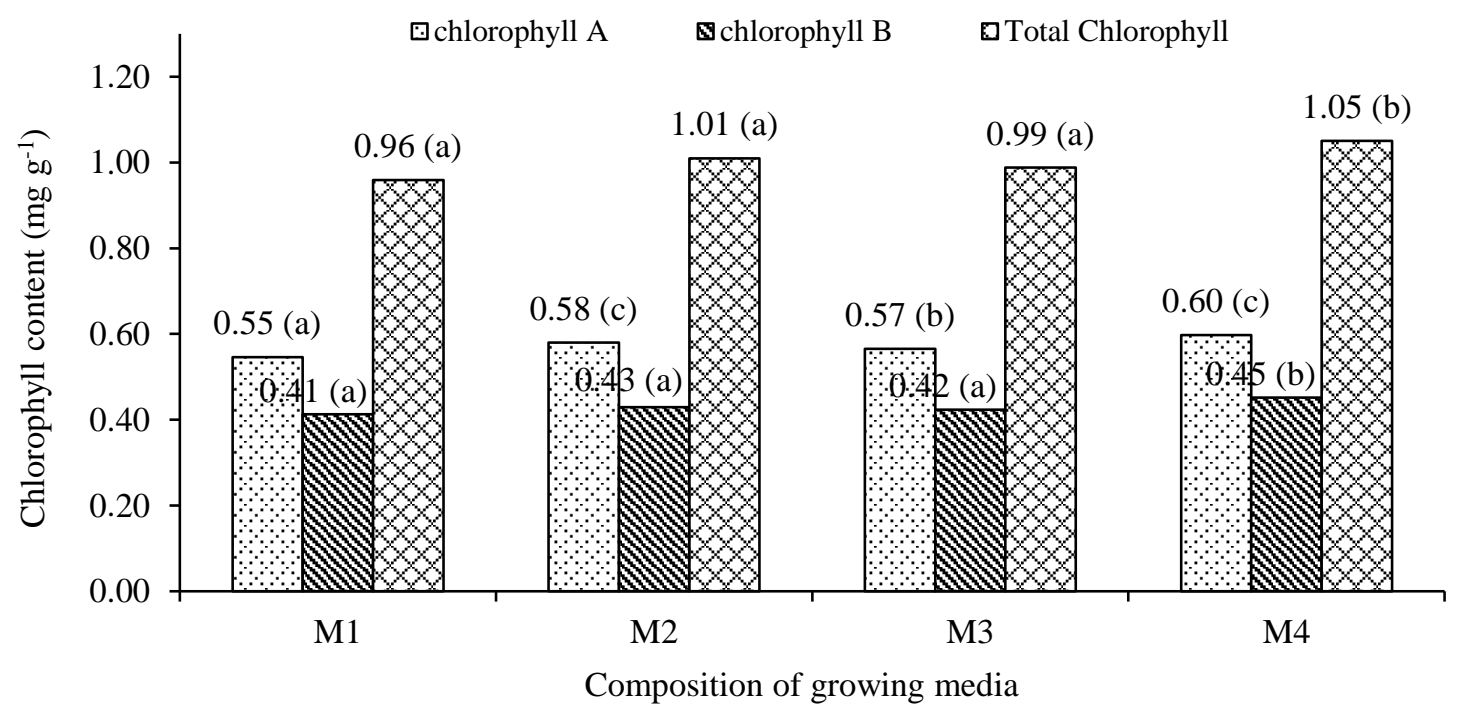

Note: $\mathrm{M} 1=55 \%$ cocopeat, $15 \%$ rice husk biochar and $30 \%$ sand; $\mathrm{M} 2=55 \%$ cocopeat, $30 \%$ rice husk biochar and $15 \%$ sand; M3 $=55 \%$ cocopeat, $15 \%$ zeolite and $30 \%$ sand; M4 $=55 \%$ cocopeat, $30 \%$ zeolite and $15 \%$ sand

Figure 3. Effect of various composition of growing media on chlorophyll content of green leafy lettuce. (Means accompanied by the same letters are not significantly different at Tukey-test, $\mathrm{P}=0.05$ ) 
Figure 4 shows that the higher the vermicompost application rate, the higher the chlorophyll content of the plant. However, the $250 \mathrm{~g} \mathrm{pot}^{-1}$ rate was not significantly different from the $200 \mathrm{~g} \mathrm{pot}^{-1}$ rate for the four types of growing media. The availability of nutrients influences chlorophyll synthesis. The structure of chlorophyll contains $\mathrm{N}$ and $\mathrm{Mg}$ (Chen and Blankenship, 2011). Therefore, vermicompost application increases chlorophyll synthesis because vermicompost contains complete nutrients. Vermicompost used in this study had a chemical composition: $\mathrm{N}$ content of $2.05 \%$, $\mathrm{P}$ content of $0.92 \%, \mathrm{~K}$ content of $1.55 \%$, $\mathrm{Ca}$ content of $3.65 \%, \mathrm{Mg}$ content of $0.5 \%$, $\mathrm{S}-\mathrm{SO}_{4}$ content of $0.15 \%$ and micro elements. Chlorophyll is vital for human health. The consumption of a diet rich in vegetables rich in chlorophyll is associated with lower incidences of oxidation-linked diseases, such as diabetes and cardiovascular disease (Arshiya, 2013; Parashar et al., 2014; Zhang et al., 2015). Alsuhaibani et al. (2017) reported that chlorophyll had important implications regarding blood sugar.

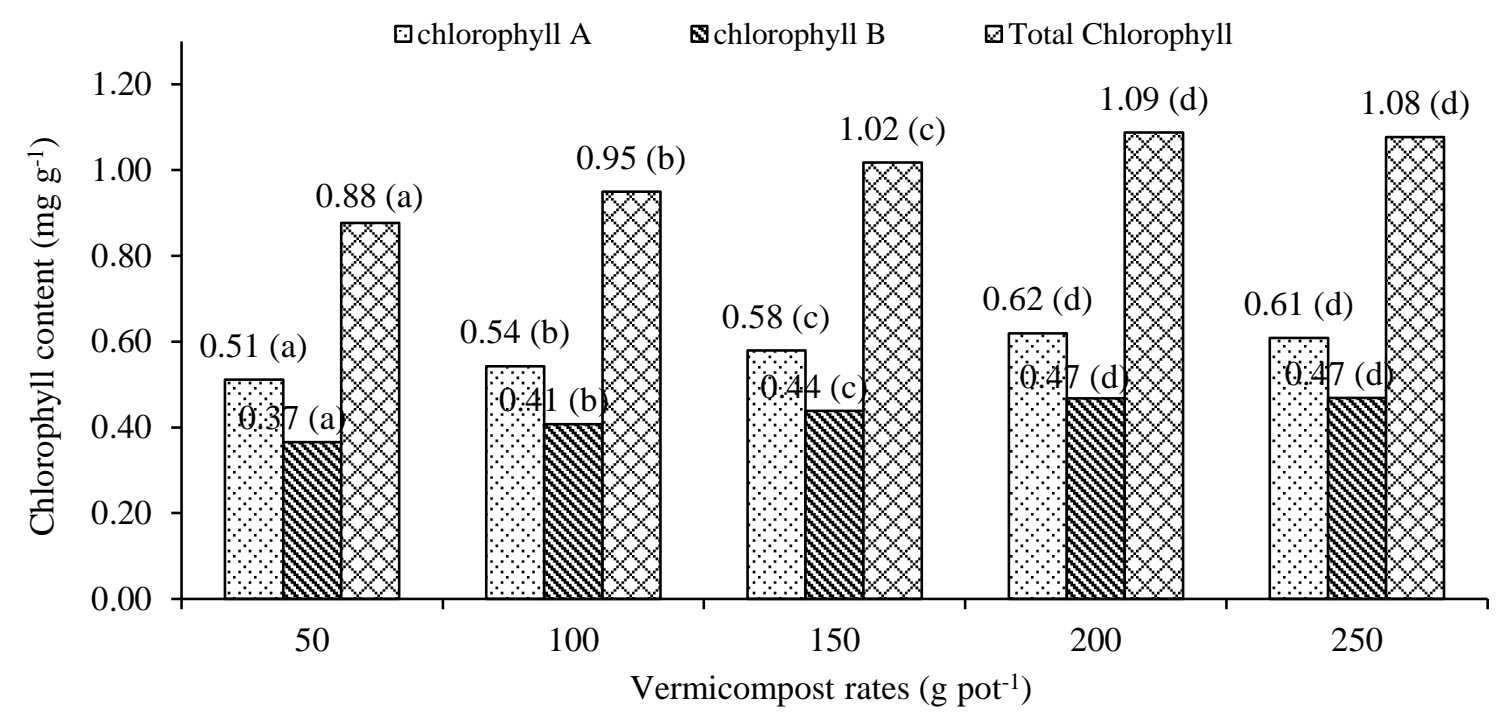

Figure 4. Effect of vermicompost rates on the chlorophyll content of green leafy lettuce grown using a soilless culture system. (Means accompanied by the same letters are not significantly different at Tukey-test, $\mathrm{P}=0.05$ )

The difference in the composition of the growing media also affects the mineral content of green leafy lettuce (Figure 5). The highest Ca content $(1.10 \%)$ was found in the M4 growing media (55\% cocopeat, $30 \%$ zeolite and $15 \%$ sand). The highest potassium content (8.47\%) was found in M2 growing media (55\% cocopeat, $30 \%$ rice husk biochar and $15 \%$ sand) and the highest phosphorous content was found in M2 growing media (55\% cocopeat, 30\% rice husk biochar and $15 \%$ sand). Zeolite can act as an ion exchanger, so that allows for cation replacement in the zeolite structure by an outside ion from the solution includes Ca cations, thereby increasing $\mathrm{Ca}$ uptake in plants (Cejka et al., 2010; Mgbemere et al., 2017). Rice husk biochar contains relatively high soluble-K (3.35 $\mathrm{cmol} \mathrm{kg}^{-1}$ ) so that it contributes to the availability of potassium $(\mathrm{K})$ in growing media
(Altland and Locke, 2012; Phuong et al., 2020). The application of biochar in the soilless substrate is essential in reducing leaching of macronutrients such as $\mathrm{N}, \mathrm{P}$ and $\mathrm{K}$ ions, thereby become available to plants (Altland and Locke, 2012).

Vermicompost application had significant effect on the mineral content of green leafy lettuce (Figure 6). High Ca content of green leafy lettuce was found in vermicompost applications of 150-250 $\mathrm{g} \mathrm{pot}^{-1}$. Meanwhile, the highest $\mathrm{K}$ and $\mathrm{P}$ contents were found in the highest vermicompost application of $250 \mathrm{~g} \mathrm{pot}^{-1}$. Vermicompost was the primary source of nutrients in this soilless culture. The increase in the vermicompost rate increased plant nutrient uptake and the plant mineral content. Previous research also shown that vermicompost's application improved the yield and quality of some organically grown vegetable plants such as pak-coi 
mustard (Nurhidayati et al., 2015) and cabbage (Nurhidayati et al., 2016). Manyuchi et al. (2013) reported that vermicompost positively impacted the availability of soil nutrient due to the presence of living organisms in the vermicompost, thereby stimulating lettuce growth.

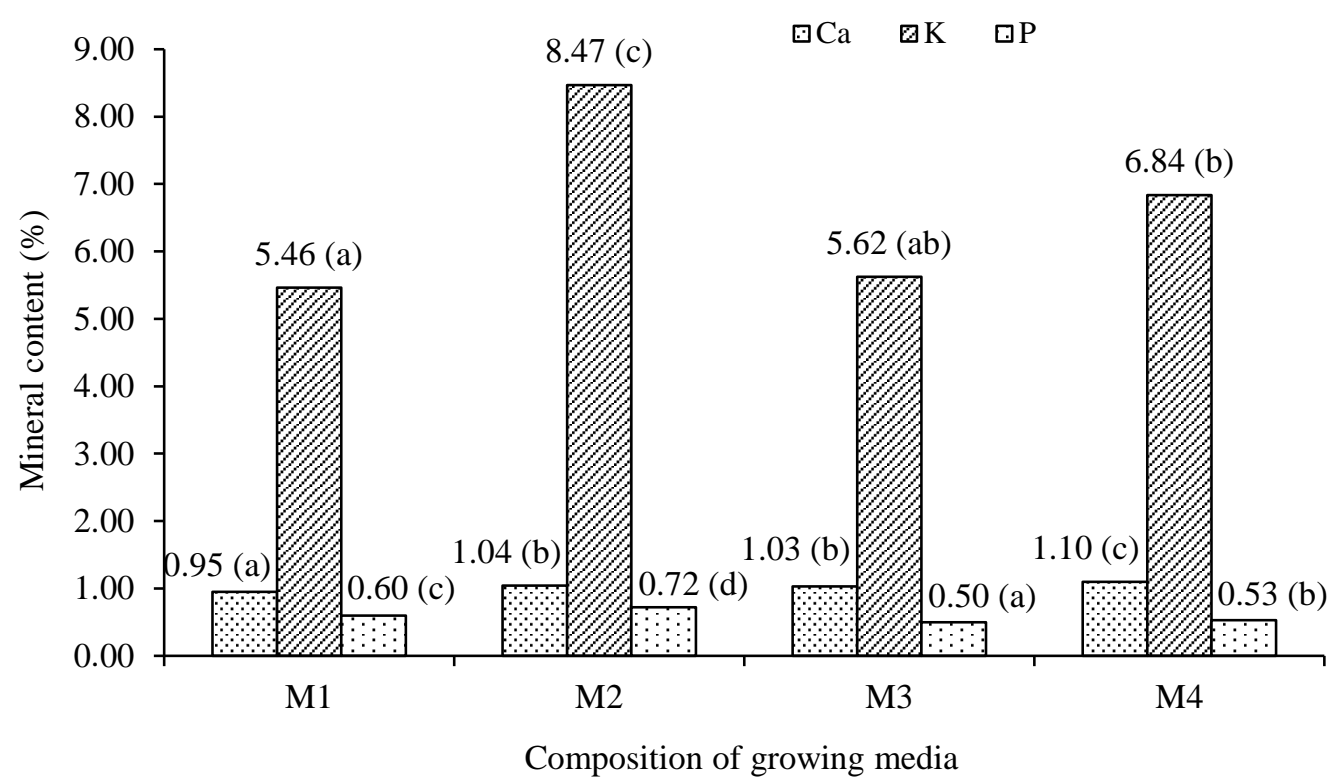

Note: $\mathrm{M} 1=55 \%$ cocopeat, $15 \%$ rice husk biochar and $30 \%$ sand; $\mathrm{M} 2=55 \%$ cocopeat, $30 \%$ rice husk biochar and $15 \%$ sand; $\mathrm{M} 3=55 \%$ cocopeat, $15 \%$ zeolite and $30 \%$ sand; $\mathrm{M} 4=55 \%$ cocopeat, $30 \%$ zeolite and $15 \%$ sand

Figure 5. Effect of various composition of growing media on mineral content of green leafy lettuce. (Means accompanied by the same letters are not significantly different at Tukey-test, $\mathrm{P}=0.05$ )

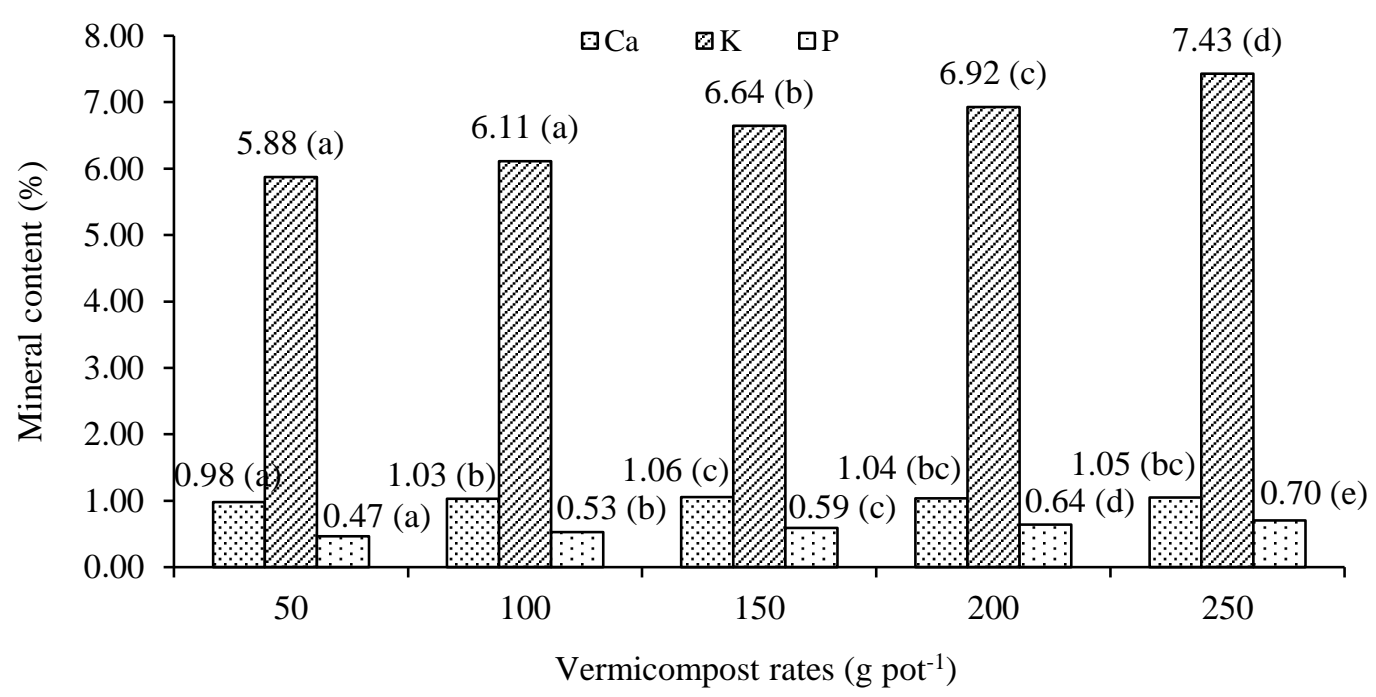

Figure 6. Effect of vermicompost rates on the mineral content of green leafy lettuce grown using a soilless culture system. (Means accompanied by the same letters are not significantly different at Tukey-test, $\mathrm{P}=0.05$ )

The M2 growing media (cocopeat 55\%, biochar $30 \%$ and sand $15 \%$ ) with vermicompost rate by $200-250 \mathrm{~g} \mathrm{pot}^{-1}$ and M4 (cocopeat $55 \%$, zeolite $30 \%$ and sand $15 \%$ ) with vermicompost rate by $150-200 \mathrm{~g} \mathrm{pot}^{-1}$ had the highest vitamin $\mathrm{C}$ content of green leafy lettuce with range 17.54$18.50 \mathrm{mg} 100 \mathrm{~g}^{-1}$ (Table 1). Each composition of the growing media produced a different 
vitamin $\mathrm{C}$ content of green leafy lettuce. In the composition of the growing media M1 (cocopeat $55 \%$, biochar $15 \%$ and sand $30 \%$ ), the highest vitamin $\mathrm{C}$ content was found at the vermicompost rate of 200-250 $\mathrm{g} \mathrm{pot}^{-1}$. In comparison, in the M3 (cocopeat 55\%, zeolite 15\% sand 30\%), the vermicompost rate of $150-200 \mathrm{~g} \mathrm{pot}^{-1}$ had the highest vitamin $\mathrm{C}$ content. This difference is caused by differences in physical, chemical and biological conditions due to differences in growing media materials and their composition, affecting the availability of water and nutrients, which affects the yield and quality of plants (Savvas and Gruda, 2018).

Table 1. Combined effect of composition of growing media and vermicompost rates on vitamin $\mathrm{C}$ content of green leafy lettuce

\begin{tabular}{|c|c|c|c|c|c|}
\hline \multirow{2}{*}{ Treatments } & \multicolumn{5}{|c|}{ Vermicompost rates $\left(\mathrm{g} \mathrm{pot}^{-1}\right)$} \\
\hline & 50 & 100 & 150 & 200 & 250 \\
\hline Composition of growing media & \multicolumn{5}{|c|}{ Vitamin $\mathrm{C}$ content $\left({\left.\mathrm{mg} 100 \mathrm{~g}^{-1}\right)}\right.$} \\
\hline Cocopeat $55 \%$, biochar $15 \%$ and sand $30 \%$ & $12.28^{\mathrm{a}}$ & $13.63^{\mathrm{ab}}$ & $15.10^{\mathrm{c}}$ & $16.32^{\text {cde }}$ & $16.78^{\mathrm{d}}$ \\
\hline Cocopeat $55 \%$, biochar $30 \%$ and sand $15 \%$ & $14.93^{\mathrm{bc}}$ & $16.94^{\mathrm{ef}}$ & $17.05^{\mathrm{ef}}$ & $18.44^{\mathrm{g}}$ & $17.54^{\mathrm{fs}}$ \\
\hline Cocopeat $55 \%$, zeolite $15 \%$ and sand $30 \%$ & $12.97^{\mathrm{a}}$ & $13.69^{\mathrm{ab}}$ & $15.66^{\text {cde }}$ & $16.81^{\mathrm{de}}$ & $15.30^{\mathrm{c}}$ \\
\hline Cocopeat $55 \%$, zeolite $30 \%$ and sand $15 \%$ & $13.52^{\mathrm{ab}}$ & $15.44^{\text {cd }}$ & $18.05^{\mathrm{fg}}$ & $18.50^{\mathrm{g}}$ & $17.15^{\mathrm{e}}$ \\
\hline
\end{tabular}

Note: Means followed by different letters are significantly different at Tukey-test, $\mathrm{P}=0.05$

\section{CONCLUSIONS}

Green leafy lettuce grown in growing media with a composition of $55 \%$ cocopeat, $30 \%$ rice husk biochar and $15 \%$ sand had the highest yield. The highest chlorophyll A, B, total chlorophyll and $\mathrm{Ca}$ content was found in the green leafy lettuce grown in growing media 55\% cocopeat, $30 \%$ zeolite and $15 \%$ sand. The green leafy lettuce grown in 55\% cocopeat, $30 \%$ rice husk biochar and $15 \%$ accumulated high $\mathrm{K}$ and $\mathrm{P}$ mineral content and vitamin $\mathrm{C}$ content. The best rate of vermicompost to produce the highest green leafy lettuce yield is $250 \mathrm{~g} \mathrm{pot}^{-1}$. While to get high quality green leafy lettuce, $200 \mathrm{~g} \mathrm{pot}^{-1}$ of vermicompost is required. Thus, the admixtures of biochar and zeolite into the cocopeat substrate for the soilless culture system of green leafy lettuce significantly affected yield and quality.

\section{ACKNOWLEDGEMENT}

The authors would like to thank Directorate of Higher Education, Ministry of Education and Culture, Indonesia for their financial support through the research grant scheme of the University Excellent Research 2020 No. 187/ SP2H/LT/DRPM/2020; 018/SP2H/AMD/LT/MU LTI/L7/2020.

\section{REFERENCES}

Altland, J. E., \& Locke, J. C. (2012). Biochar affects macronutrient leaching from a soilless substrate. HortScience, 47(8), 1136-1140. https://doi.org/10.21273/hortsci.47.8.1136

Alsuhaibani, A. M., ALkehayez, N. M., Alshawi, A. H., \& Al-Faris, N. A. (2017). Effects of chlorophyll on body functioning and blood glucose levels. Asian Journal of Clinical Nutrition, 9(2), 64-70. https://dx.doi.org/ 10.3923/ajcn.2017.64.70

Arshiya, S. (2013). The antioxidant effect of certain fruits: - A review. Journal of Pharmaceutical Sciences and Research, 5(12), 265-268. Retrieved from https://www.jpsr. pharmainfo.in/Documents/Volumes/vol5issue 12/jpsr05121304.pdf

Asaduzzaman, M., Saifullah, M., Mollick, A. K. M., Hossain, S. R., Halim, G. M. A., \& Asao, T. (2015). Influence of soilless culture substrate on improvement of yield and produce quality of horticultural crops. In Soilless Culture - Use of Substrates for the Production of Quality Horticultural Crops. IntechOpen. https://doi.org/10.5772/59708

Barrow, C. J. (2012). Biochar: Potential for countering land degradation and for improving agriculture. Applied Geography, 34, 21-28. https://doi.org/10.1016/j.apgeog.2011.09.008

Biederman, L. A., \& Harpole, W. S. (2013). Biochar and its effects on plant productivity and nutrient cycling: A meta-analysis. $G C B$ Bioenergy, 5(2), 202-214. https://doi.org/ 
10.1111/gcbb.12037

Cejka, J., Corma, A., \& Zones, S. (2010). Zeolites and catalysis: synthesis, reactions and applications. Weinheim, Germany: WileyVCH Verlag GmbH \& Co. KGaA. http:// doi.org/10.1002/9783527630295

Chen, M., \& Blankenship, R. E. (2011). Expanding the solar spectrum used by photosynthesis. Trends in Plant Science, 16(8), 427-431. https://doi.org/10.1016/ j.tplants.2011.03.011

Cheng, Y., Cai, Z. C., Chang, S. X., Wang, J., \& Zhang, J. B. (2012). Wheat straw and its biochar have contrasting effects on inorganic $\mathrm{N}$ retention and $\mathrm{N}_{2} \mathrm{O}$ production in a cultivated Black Chernozem. Biology and Fertility of Soils, 48(8), 941-946. https://doi.org/ 10.1007/s00374-012-0687-0

Clough, T. J., Condron, L. M., Kammann, C., \& Müller, C. (2013). A review of biochar and soil nitrogen dynamics. Agronomy, 3(2), 275-293. https://doi.org/10.3390/agronomy3020275

Clough, T. J., \& Condron, L. M. (2010). Biochar and the nitrogen cycle: Introduction. Journal of Environmental Quality, 39(4), 1218-1223. https://doi.org/10.2134/jeq2010.0204

Dumroese, R. K., Heiskanen, J., Englund, K., \& Tervahauta, A. (2011). Pelleted biochar: Chemical and physical properties show potential use as a substrate in container nurseries. Biomass and Bioenergy, 35(5), 2018-2027. https://doi.org/10.1016/j.biombio e.2011.01.053

Elad, Y., David, D. R., Harel, Y. M., Borenshtein, M., Kalifa, H. B., Silber, A., \& Graber, E. R. (2010). Induction of systemic resistance in plants by biochar, a soil-applied carbon sequestering agent. Phytopathology, 100(9), 913-921. https://doi.org/10.1094/PHYTO-100 $-9-0913$

El-Kazzaz, K. A. \& El-Kazzaz, A. A. (2017). Soilless agriculture a new and advanced method for agriculture development: an introduction. Agricultural Research \& Technology: Open Access Journal, 3(2), 555610. DOI: 10.19080/ARTOAJ.2017.03. 555610009.

Farrell, M., Macdonald, L. M., Butler, G.,
Chirino-Valle, I., \& Condron, L. M. (2014). Biochar and fertiliser applications influence phosphorus fractionation and wheat yield. Biology and Fertility of Soils, 50(1), 169-178. https://doi.org/10.1007/s00374-013-0845-Z

Fredeen, A. L., Raab, T. K., Rao, I. M., \& Terry, N. (1990). Effects of phosphorus nutrition on photosynthesis in Glycine $\max (\mathrm{L}$.$) Merr.$ Planta, 181(3), 399-405. https://doi.org/ 10.1007/BF00195894

Graber, E. R., Harel, Y. M., Kolton, M., Cytryn, E., Silber, A., David, D. R., Tsechansky, L., Borenshtein, M., \& Elad, Y. (2010). Biochar impact on development and productivity of pepper and tomato grown in fertigated soilless media. Plant and Soil, 337(1), 481-496. https://doi.org/10.1007/s11104-010-0544-6

Gruda, N., Qaryouti, M. M., \& Leonardi, C. (2013). Growing media. In Good Agricultural Practices for greenhouse vegetable crops: Principles for Mediterranean climate areas, pp. 271-301. Rome: FAO Plant Production and Protection Paper. Retrieved from http:// www.fao.org/3/i3284e/i3284e.pdf

Gruda, N., Gianquinto, G., Tüzel, Y., and Savvas, D. (2016). Culture soil-less. In Encyclopedia of soil sciences (R. Lal (ed.); 3rd ed., pp. 533537). CRC Press, Taylor \& Francis Group. https://doi.org/10.1081/e-ess3

Gruda, N., Savvas, D., Colla, G., \& Rouphael, Y. (2018). Impacts of genetic material and current technologies on product quality of selected greenhouse vegetables - A review. European Journal of Horticultural Science, 83(5), 319328. https://doi.org/10.17660/eJHS.2018/83.5 .5

Jouquet, E., Bloquel, E., Doan, T. T., Ricoy, M., Orange, D., Duc, T. T., Jouquet, E., Bloquel, E., Ricoy, M., Orange, D., \& Rumpel, C. (2011). Do compost and vermicompost improve macronutrient retention and plant growth in degraded tropical soils? Compost Science and Utilization, 19(1), 15-24. https:// doi.org/10.1080/1065657X.2011.10736972

Jouquet, P., Plumere, T., Thu, T. D., Rumpel, C., Duc, T. T., \& Orange, D. (2010). The rehabilitation of tropical soils using compost and vermicompost is affected by the presence of endogeic earthworms. Applied Soil Ecology, 
46(1), 125-133. https://doi.org/10.1016/j.ap soil.2010.07.002

Kalra, Y (1997). Handbook of reference methods or plant analysis $\left(1^{\text {st }}\right.$ ed). CRC Press, Taylor and Francis Group. https://doi.org/10.1201/ 97803678022337802233.

Khan, F. A., Kurklu, A., Ghafoor, A., Ali, Q., Umair, M., \& Shahzaib. (2018). A review on hydroponic greenhouse cultivation for sustainable agriculture. International Journal of Agriculture, Environment and Food Sciences, 2(2), 59-66. http://derg_park.gov.tr/ jaefs.

Laird, D. A. (2008). The charcoal vision: A win-win-win scenario for simultaneously producing bioenergy, permanently sequestering carbon, while improving soil and water quality. Agronomy Journal, 100(1), 178-181. https://doi.org/10.2134/agronj2007 .0161

Lazcano, C., \& Domínguez, J. (2011). The use of vermicompost in sustainable agriculture: impact on plant growth and soil fertility. In Soil Nutrient: Environmental Health Physical, Chemical and Biological Factors. Hauppauge, New York, US: Nova Science Publishers, Inc. Retrieved from http://jdguez. webs.uvigo.es/wp-content/uploads/2012/01/th e-use-of-vermicompost.pdf

Lehmann, J., da Silva Jr., J. P., Steiner, C., Nehls, T., Zech, W., \& Glaser B. (2003). Nutrient availability and leaching in an archaeological Anthrosol and a Ferralsol of the Central Amazon basin: fertilizer, manure and charcoal amendments. Plant and Soil, 249, 343-357. https://doi.org/https://doi.org/10.1023/A:1022 833116184

Lehmann, J., \& Joseph, S. (2009). Biochar for environmental management: science and technology $\left(1^{\text {st }} \mathrm{ed}\right)$. Earthscan. Retrieved from http://www.css.cornell.edu/faculty/lehmann/p ubl/First\%20proof\%2013-01-09.pdf

Li, Y., He, N., Hou, J., Xu, L., Liu, C., Zhang, J., Wang, Q., Zhang, X., \& Wu, X. (2018). Factors influencing leaf chlorophyll content in natural forests at the biome scale. Frontiers in Ecology and Evolution, 6, 64. https://doi.org/ $10.3389 /$ fevo.2018.00064
Liang, B., Lehmann, J., Solomon, D., Kinyangi, J., Grossman, J., O'neill, B., Skjemstad, J. O., Thies, J., Luizão, F. J., Petersen, J., \& Neves, E. G. (2006). Black carbon increases cation exchange capacity in soils. Soil Science Society of America Journal, 70(5), 1719-1730. https://doi.org/10.2136/sssaj2005.0383

Manyuchi, M. M., Mudamburi, T., Phiri, A., \& Muredzi, P. (2013). Impact of vermicompost on lettuce cultivated soil. international journal of inventive engineering and sciences, 1(11), 41-43. Retrieved from https://www.research gate.net/publication/257933663_Impact_of_v ermicompost_on_lettuce_cultivated_soil

Mgbemere, H. E., Ekpa, I. C., \& Lawal, G. I. (2017). zeolite synthesis, characterisation and application areas: A Review. International Research Journal of Environmental Sciences, 6(10), 45-59. Retrieved from http://www.isca. in/IJENS/Archive/v6/i10/7.ISCA-IRJEvS-201 7-072.php

Nurhidayati, Ali, U., \& Murwani, I. (2016). Yield and quality of cabbage (Brassica oleracea $\mathrm{L}$. var. Capitata) under organic growing media using vermicompost and earthworm Pontoscolex corethrurus inoculation. Agriculture and Agricultural Science Procedia, 11, 5-13. https://doi.org/10.1016/ j.aaspro.2016.12.002

Nurhidayati, Ali, U., \& Murwani, I. (2015). Influence of the kind of vermicompost material and earthworm Pontoscolex corethrurus population on the yield and quality of phak-coi mustard (Brassica rapa L.) with organic potting media. Proceeding of International Conference on Life Science and Biotechnology: Exploration and Conservation of Biodiversity, 168-176. Retrieved from https://www.researchgate.net/ profile/Lita-Meilina/publication/337211094_ PROCEEDING-ICOLIB2015/links/5dcbd1cd 458515143507101a/PROCEEDING-ICOLIB 2015.pdf\#page $=187$

Nurhidayati, Machfudz, M., \& Murwani, I. (2017). Pertumbuhan, hasil dan kualitas tanaman brokoli (Brassica oleracea L.) sebagai respon terhadap aplikasi tiga macam vermikompos dengan sistem penanaman secara organik. Prosiding Seminar Nasional 
Fakultas Pertanian Universitas Nasional: Optimalisasi Pemanfaatan Sumberdaya Lokal Menuju Kemandirian Pangan Nasional yang Berkelanjutan, 175-190. Retrieved from https://scholar.google.com/scholar?cluster=10 919619192482386044\&hl=en\&oi=scholarr

Parashar, S., Sharma, H., \& Garg, M. (2014). Antimicrobial and antioxidant activities of fruits and vegetable peels: A review. Journal of Pharmacognosy and Phytochemistry JPP, 3(31), 160-164. Retrieved from https://www. phytojournal.com/vol3Issue1/Issue_may_201 4/23.1.pdf

Phuong, N. T. K., Khoi, C. M., Ritz, K., Linh, T. B., Minh, D. D., Duc, T. A., Sinh, N. V., Linh, T. T., \& Toyota, K. (2020). Influence of rice husk biochar and compost amendments on salt contents and hydraulic properties of soil and rice yield in salt-affected fields. Agronomy, 10(8), 1101. https://doi.org/ 10.3390/agronomy10081101

Rembialkowska, E. (2007). Review quality of plant products from organic agriculture. Journal of the Science of Food and Agriculture, 87, 2757-2762. https://doi.org/ $10.1002 /$ jsfa.3000

Savvas, D. (2003). Hydroponics: A modern technology supporting the application of integrated crop management in greenhouse. Food, Agriculture \& Environment, 1(1), 8086. Retrieved from https://agris.fao.org/agrissearch/search.do?recordID=FI2016100234

Savvas, D., Gianquinto, G., Tuzel, Y., \& Gruda, N. (2013). Soilless culture. In Good Agricultural Practices for greenhouse vegetable crops: Principles for Mediterranean climate areas, pp. 271-301. Rome: FAO Plant Production and Protection Paper. Retrieved from http://www.fao.org/3/i3284e/i3284e.pdf

Savvas, D., \& Gruda, N. (2018). Application of soilless culture technologies in the modern greenhouse industry - A review. European Journal of Horticultural Science, 83(5), 280293. https://doi.org/10.17660/eJHS.2018/83. 5.2

Science Communication Unit, University of the West of England. (2013). Science for Environment Policy In-depth Report: Soil Contamination: Impacts on Human Health.
European Commission's Directorate-General Environment. Retrieved from https://ec. europa.eu/environment/integration/research/n ewsalert/pdf/IR5_en.pdf

Solaiman, Z. M., Blackwell, P., Abbott, L. K., \& Storer, P. (2010). Direct and residual effect of biochar application on mycorrhizal root colonisation, growth and nutrition of wheat. Australian Journal of Soil Research, 48(6-7), 546-554. https://doi.org/10.1071/SR10002

Steiner, C., Glaser, B., Teixeira, W. G., Lehmann, J., Blum, W. E. H., \& Zech, W. (2008). Nitrogen retention and plant uptake on a highly weathered central Amazonian Ferralsol amended with compost and charcoal. Journal of Plant Nutrition and Soil Science, 171(6), 893-899. https://doi.org/10.1002/jpln.200625 199

Steiner, C., Teixeira, W. G., Lehmann, J., Nehls, T., De MacÊdo, J. L. V., Blum, W. E. H., \& Zech, W. (2007). Long term effects of manure, charcoal and mineral fertilization on crop production and fertility on a highly weathered Central Amazonian upland soil. Plant and Soil, 291(1-2), 275-290. https://doi.org/ 10.1007/s11104-007-9193-9.

United Nations. (2019). World population 2019. Department of Economic and social Affairs. Population Division. Retrieved January, 20, 2021, www.unpopulation.org

Uzoma, K. C., Inoue, M., Andry, H., Fujimaki, H., Zahoor, A., \& Nishihara, E. (2011). Effect of cow manure biochar on maize productivity under sandy soil condition. Soil Use and Management, 27(2), 205-212. https://doi.org/ 10.1111/j.1475-2743.2011.00340.x

Vaccari, F. P., Baronti, S., Lugato, E., Genesio, L., Castaldi, S., Fornasier, F., \& Miglietta, F. (2011). Biochar as a strategy to sequester carbon and increase yield in durum wheat. European journal of agronomy, 34(4), 231238. https://doi.org/10.1016/j.eja.2011.01.006

Viger, M., Hancock, R. D., Miglietta, F., \& Taylor, G. (2014). More plant growth but less plant defence? First global gene expression data for plants grown in soil amended with biochar. GCB Bioenergy, 7(4), 658-672. https://doi.org/10.1111/gcbb.12182

Williams, C. M. (2002). Nutritional quality of 
organic food: shades of grey or shades of green? Proceedings of the Nutrition Society, 61(1), 19-24. https://doi.org/10.1079/pns200 1126

Worthington, V. (2001). Nutritional quality of organic versus conventional fruits, vegetables, and grains. Journal of Alternative and Complementary Medicine, 7(2), 161-173. https://doi.org/10.1089/107555301750164244

Zhang, Y. J., Gan, R. Y., Li, S., Zhou, Y., Li, A. N., Xu, D. P., \& Li, H. B. (2015). (2015). Antioxidant phytochemicals for the prevention and treatment of chronic diseases. Molecules, 20(12), 21138-21156. https://doi.org/10.3390/ molecules201219753 